\title{
PROBLEMATIKA PEMBELAJARAN DARING DAN SOLUSINYA STUDI KASUS DI SMKN 4 YOGYAKARTA
}

\author{
JAMADI \\ SMKN 4 Yogyakarta \\ e-mail : jamadiyogya@gmail.com
}

\begin{abstract}
ABSTRAK
Kebijakan pembelajaran daring merupakan upaya pencegahan penyebaran covid-19. Meski ada kekurangan, pembelajaran daring merupakan solusi saat ini. Pembelajaran dengan memanfaatkan aplikasi berbasis teknologi Informasi dan jaringan. Penelitian ini mengungkap problematika dan solusinya dengan kasus di SMKN 4 Yogyakarta. Metode penelitian deskriptif kualitatif yang dirancang menggambarkan data penelitian secara obyektif, dengan analisis data induktif, mementingkan proses dan makna. Teknik pengumpulan, dengan pengamatan, wawancara, dan dokumentasi dan peneliti sebagai kunci. Hasil wawancara ditemukan problematika yang dihadapi peserta didik, guru dan orang tua. Bagi peserta didik, yang menonjol; paket data, berturut kondisi jenuh, konsentrasi terganggu, orang tua kurang mendukung, pembelajaran belum familiar, pemakaian gawai bersama dan jaringan tidak stabil. Problematika guru; paling menonjol semangat belajar rendah, kompetensi menurun, sulitnya penanaman karakter, komunikasi serta masih ada guru terkendala pembelajaran. Sedangkan orang tua; kesulitan ekonomi, kesempatan, pemahaman pembelajaran yang keliru dan masalah komunikasi. Dari penelitian didapatkan, solusi problematika dalam pembelajaran daring, secara umum perlu pemahaman yang sama bahwa pendidikan merupakan tanggung jawab bersama. Komunikasi diharapkan terbangun secara baik, sehingga problematika dapat diselesaikan. Masalah kesulitan ekonomi, paket data, jaringan, gawai untuk bersama dipecahkan secara komprehensif, kolaborasi orang tua, guru dan fihak lain. Kesulitan pembelajaran daring dipecahkan dengan mengadakan pelatihan bagi guru, pendampingan peserta didik dan sosialisasi kepada orang tua. Masalah kesempatan dan sarana pembelajaran, orang tua dan peserta didik diharap membuat skala prioritas. Problem kurang semangat karena jenuh, konsentrasi terganggu, ditemukan solusinya guru melaksanakan pembelajaran inovatif, kreatif serta menarik, bahkan pembelajaran diharap sekaligus hiburan. Capaian kopetensi masa darurat, perlu perampingan KD substansial saja, serta penanaman karakter akhlak mulia, perlu strategi dan penilaian yang sesuai. Diharapkan penelitian ini dapat memberikan gambaran dan acuan bagi penelitian berikutnya dan fihak yang terkait.
\end{abstract}

Kata Kunci : Pandemi Covid-19; Problematika Pembelajaran; Pembelajaran Daring

\section{PENDAHULUAN}

Sejak virus Corona (Covid 19) melanda wilayah Indonesia bahkan dunia tahun lalu yang ditandai dengan dikeluarkannya ketetapan WHO 11 Maret 2020, covid 19 sebgai pandemi, dan mengacu pada keputusan bersama Menteri Pendidikan dan Kebudayaan, menteri agama, menteri kesehatan dan Menteri Dalam Negeri tentang panduan penyelenggaraan pembelajaran pada tahun 2020/2021 dan tahun akademik 2020/2021 (SE Mendikbud, 2020). Maka Kementerian Pendidikan dan Kebudayaan telah menerapkan kebijakan learning from home atau belajar dari rumah, dengan pembelajaran daring. Dijelaskan dalam undang-undang nomor 20 tahun 2003 bahwa PJJ, atau seterusnya daring adalah pendidikan yang peserta didiknya terpisah dari pendidik dan pembelajarannya menggunakan berbagai sumber belajar melalui teknologi komunikasi, informasi dan media lainnya. Sedangkan prinsip pembelajaran jarak jauh sesuai dengan surat edaran Menteri Pendidikan dan Kebudayaan No. 4 tahun 2020 untuk keselamatan dan kesehatan lahir dan bathin peserta didik, kepala satuan pendidikan seluruh warga satuan pendidikan ( Sarwa, 2020). Untuk pelaksanaan, pembelajaran daring meniadakan tatap muka secara langsung antara guru dengan guru, guru dengan peserta didik, peserta didik satu dengan yang lainya. Tetapi dengan cara online atau daring yang menggunakan jaringan 
internet, bisa dengan menggunakan kan aplikasi Whatsapp, telegram, zoom meeting, Google meet, Google classroom, YouTube dan aplikasi lainnya.

Mencermati keadaan peserta didik saat ini, sebagian peserta didik tidak memiliki handphone Android yang support terhadap aplikasi daring atau komputer yang menunjang pembelajaran daring, sebagian memiliki 1 untuk bersama saudara atau orang tua, sehingga tidak dapat menyelesaikan tugas tepat waktu. Juga masalah kurangnya kuota bagi keluarga dari kalangan menengah bawah. Sebab lain masalah jaringan internet yang tidak stabil, karena peserta didik tinggal di daerah pedesaan dan terpencil. Masalah lainya adalah masalah perubahan yang mendadak dari cara belajar konvensional ke sistem belajar daring yang terasa tiba-tiba, akibat pandemi covid 19 yang memaksa pembelajaran dengan teknologi informasi. Keadaan ini membuat berat bagi perserta didik dalam memenuhi tuntutan pembelajaran dan kompetensi yang akan dicapai, sesuai amanat UU Sisdiknas Pasal 5 ayat 1 setiap warga negara mempunyai hak yang sama untuk memperoleh pendidikan yang bermutu. Terutama bagi Peserta didik SMK Negeri 4 Yogyakarta, banyak orang tua dari kalangan menengah bawah.

Selain masalah peserta didik, ternyata persiapan guru terhadap masalah pembelajaran daring. dimana perpindahan dari pembelajaran konvensional ke sistem daring yang terasa tibatiba, tanpa adanya persiapan dan perencanaan yang matang, akibat adanya pandemi covid 19. Akhirnya guru tidak siap menghadapi perubahan dengan pembelajaran dengan teknologi dan informasi (Asmuni, 2020). Hal ini mungkin dialami terutama guru-guru generasi tua.

Meski Pembelajaran daring masih ada sejumlah masalah, tetap menjadi salah satu solusi alternatif pembelajaran di masa pandemi saat ini, karena focus saat ini adalah menjaga kesehatan dan mencegah penyebaran covid 19 yang sampai saat ini masih cukup tinggi. Selanjutnya dalam kajian ini diajukan sebuah pertanyaan bagaimana problematika pembelajaran daring di SMKN 4 Yogyakarta. dan bagaimana solusinya? Hasil penelitian Diskriptif Kualitatif ini diharapkan Menjadi bahan informasi si dan rujukan dalam mengambil kebijakan dalam melaksanakan pembelajaran daring, baik bagi guru, orang tua, peserta didik, sekolah maupun pemerintah daerah.

\section{METODE PENELITIAN}

Metode Penelitian ini adalah penelitian deskriptif kualitatif yang dirancang untuk menggambarkan data penelitian secara obyektif. Penelitian kualitatif ini peneliti berperan partisipan, bukan obyek tetapi sebagai subyek yang dapat menentukan arah (Rico, J, 2010). Sedangkan Bogdan dan Biklen berpendapat karakteristik penelitian kualitatif dilakukan dalam kondisi alamiah, lansung ke sumber data dan peneliti sebagai instrumen kunci, data terkumpul berbentuk kata-kata atau gambar, dengan analisis data induktif dan menekankan proses dan makna dari sekedar angka dan produk (dalam Anggito, A \& Setiawan, J, 2018; Nugraheni,F, 2014). Dalam hal ini peneliti hanya ingin menggambarkan problematika pembelajaran daring dan pemecahannya di SMKN 4 Yogyakarta secara obyektif.

Teknik pengumpulan data dilakukan peneliti secara langsung, melalui 3 cara : wawancara, pengamatan dan dokumentasi. Menurut Sugiono pengumpulan data diperoleh dari hasil wawancara, catatan lapangan dan dokumentasi (dalam Mahpudin, 2021). Pertama, wawancara dilakukan kepada guru, peserta didik, orang tua dan fihak sekolah baik secara langsung maupun tidak langsung melalui pertemuan, Whatsapp, telepon dan media online lain. Kedua, pengamatan dengan seksama problematika yang dihadapi guru, peserta didik, sekolah dan orang tua. Bahkan mengamati fenomena dibalik fakta yang ada. Ketiga, dokumentasi terkait sebagai pendukung dan penguat jika diperluakan. Sebagai sumber data sekunder peneliti melakukan penelusuran berbagai literatur yang berkaitan dengan penelitian ini, baik berupa buku, artikel dan informasi lain yang relevan. 


\section{Hasil Penelitian}

Pandemi covid 19 yang terjadi di Indonesia, mengharuskan semua kegiatan dilakukan dengan menjaga jarak atau social distancing antara manusia satu dengan yang lainnya. Penerapan social distancing menggeser berbagai aspek kehidupan termasuk di dunia pendidikan dengan pembelajaran dilakukan dengan metode /atau online untuk mencegah penyebaran penyebaran Covid-19. Keadaan yang darurat ini mengharuskan semua komponen menyesuaikan dengan pembelajaran berbasis teknologi ini. Sebagai lembaga pendidikan SMK Negeri 4 Yogyakarta juga menerapkan pembelajaran Jarak Jauh (PJJ) atau daring sejak bulan maret 2020, sesuai dengan Surat Keputusan Bersama 4 menteri. Meski dalam pelaksanaan pembelajaran ini tidak terlepas dari problematika yang muncul. Dari wawancara dengan beberapa guru dan siswa SMKN 4 Yogyakarta ditemukan problematika yang ada dan pada penelitian ini difokuskan pada problematika yang dihadapi peserta didik, guru dan orang tua. Dan hasil penelitian sebagai berikut.

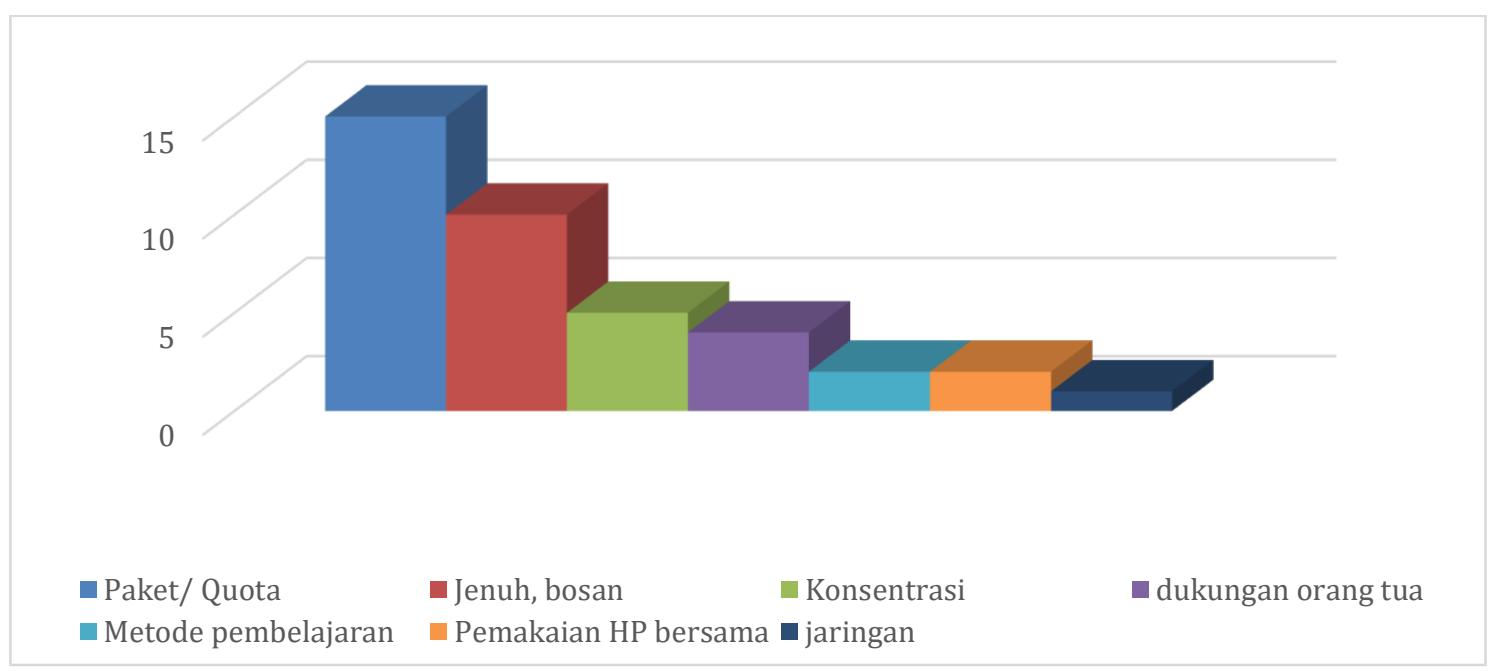

\section{Gambar 1. Problematika bagi peserta didik}

Dari gambar di atas dapat disampaikan problematika yang dihadapi peserta didik, Pertama, kurangnya paket atau kuota data, ini merupakan problematika yang paling menonjol dihadapi oleh peserta didik, mengingat setiap hari banyak tugas yang harus menggunakan kuota dari masing-masing mata pelajaran (wawancara Ajeng XII, 10 Agustus 2021). Sementara Orang tua merasa berat menyediakan paket atau kuota data, terutama orang tua kelas menengah bawah padahal ini jumlah terbesar di SMKN 4 Yogyakarta (wawancara Rini, BK, 8 Agustus 2021). Kedua, merasa jenuh dengan keadaan yang sudah sekian lama lebih 1 tahun jarang keluar rumah, menyebabkan kurangnya sosialisasi dengan pihak luar termasuk teman-teman sangat kurang (wawancara Supriyadi BK, 12 Agustus 2021). Ketiga, kurangnya konsentrasi dalam belajar disebabkan lingkungan atau konten yang kurang mendukung. Keempat, dorongan dan dukungan orang tua kurang, baik berupa fasilitas belajar, pendampingan, finansial, bahkan ada orang tua yang justru meminta peserta didik membantu pekerjaan orang tua disaat jam pembelajaran, yang seharusnya didorong untuk mengikuti pembelajaran (wawancara Rofik XII : 19 Agustus 2021). Kelima, kurangnya pemahaman metode atau aplikasi pembelajaran daring, terutama bagi peserta didik kelas 10 , terlebih bagi peserta didik yang belum pernah menggunakan aplikasi daring (wawancara Luvia, 19 Agustus 2021). Keenam, pemakaian gawai (gadget) secara bersama baik dengan orang tua atau saudara. Informasi dari jumlah peserta didik SMKN 4 Yogakarta hampir 1700, saat ini hampir separuhnya dari keluarga kurang beruntung, bahkan ditemukan satu gawai untuk sekeluarga (wawancara Rini BK, 3 Agustus 2021). Ketujuh, masalah jaringan internet yang tidak stabil, bagi sebagian kecil peserta didik yang tinggal di pegunungan. (wawancara Herbimo, 22 Agustus 2021). 


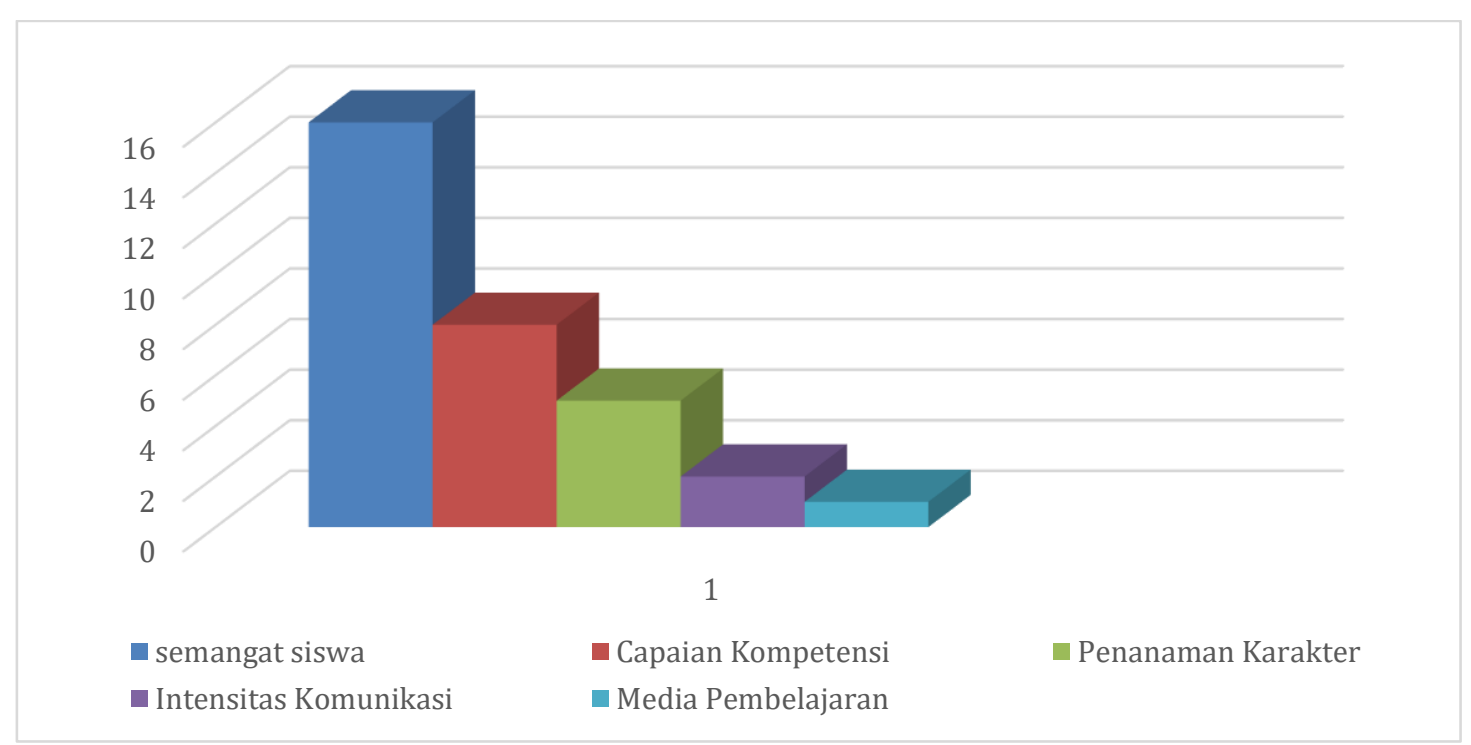

Gambar 2 Problematika yang dihadapi Guru

Sedangkan problematika yang dihadapi para guru dari hasil temuan dalam penelitian ini adalah: Pertama, kurangnya respon peserta didik saat jam pembelajaran yang ditunjukkan dari lambatnya peserta didik dalam mengikuti pembelajaran, terutama pada jam-jam awal, angka partisipasi pembelajaran ada yang kurang dari 2/3 dalam kelas tertentu (wawancara Minyati, 18 Agustus 2021). Kedua, kompetensi pembelajaran yang tidak tercapai sebagaimana keadaan normal bahkan hanya tercapai $60 \%$ dari kompetensi yang seharusnya dicapai (wawancara Bowo, 6 Agustus 2021). Ketiga, penanaman karakter karena dapat melihat secara langsung karakter anak sebagaimana keadaan normal, karena tugas guru tidak hanya mengajar tetapi juga mendidik. Keempat, intensitas komunikasi anatara guru dengan peserta didik sangat kurang, terlebih dengan anak-anak yang memang bermasalah. Kelima, penguasaan media pembelajaran yang bernuansa teknologi ini pada awal masa pandemi covid-19 masih menghadapi kesulitan dan sampai saat ini tinggal kurang dari 5 orang dari 118 guru di SMKN 4 Yogyakarta, yang rata-rata memasuki masa pensiun, Sebagian besar dengan pembelajaran daring tidak masalah (wawancara Waka. Kurikulum, 19 Agustus 2021). Dapat dilihat pada gambar 3 berikut.

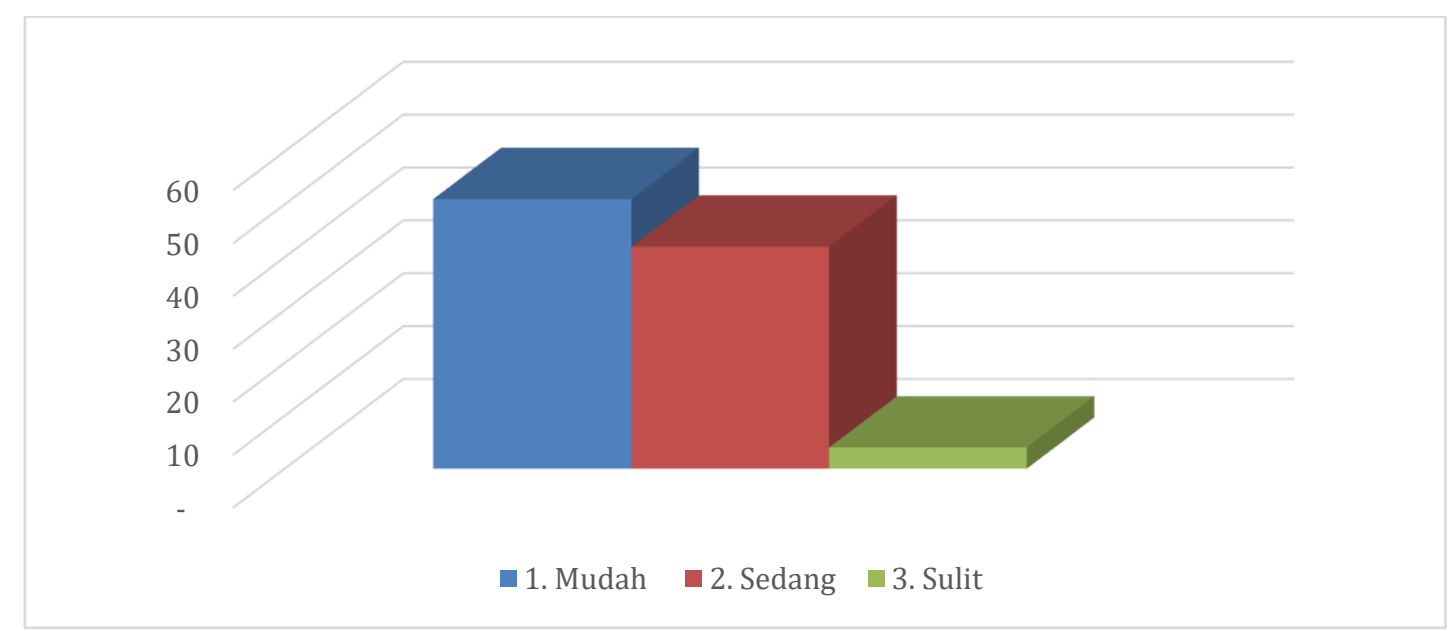

Gambar 3 Pemahaman dan Penerapan Teknologi Pembelajaran Guru 


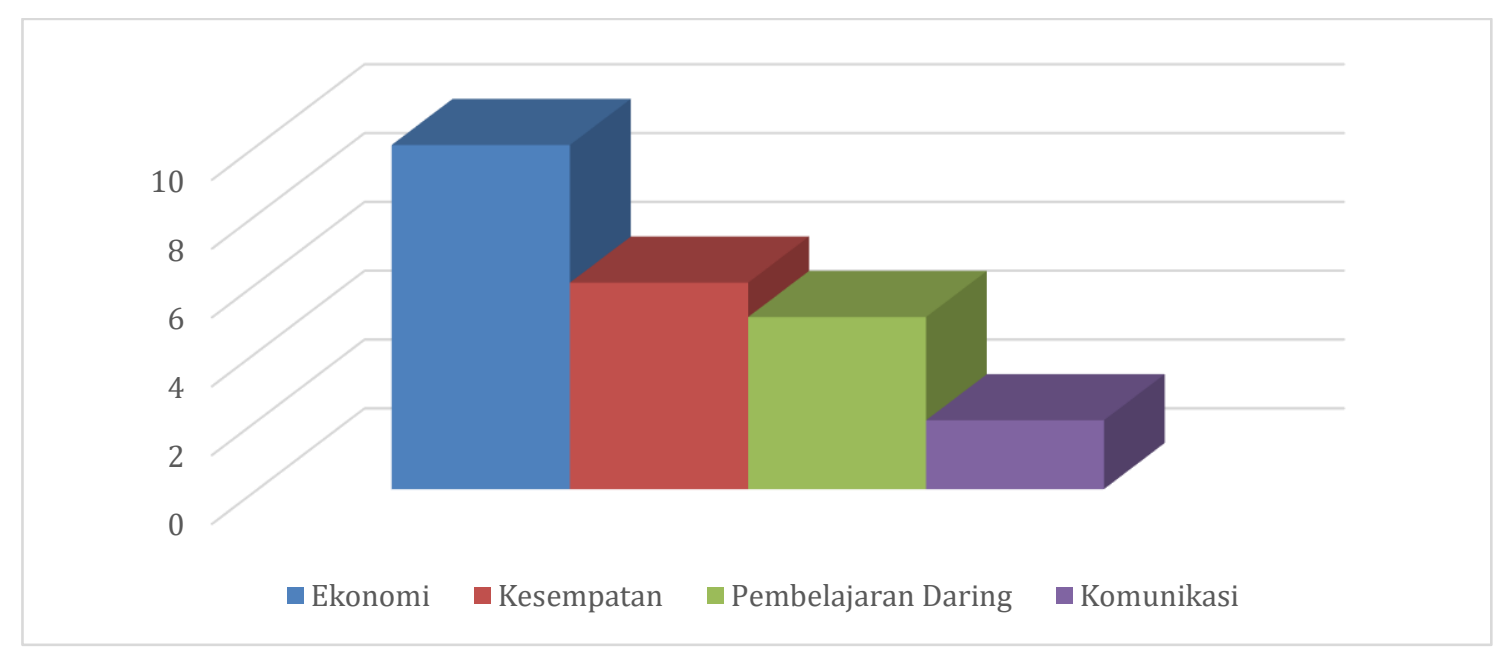

Gambar 4. Problematika bagi Orang tua

Dari sisi orang tua penelitian ini menemukan problematika yang dihadapi orang tua. Pertama, problematika ekonomi, terlebih lagi dampak pandemi covid-19 banyak keluarga yang tidak dapat memenuhi fasilitas belajar putra putrinya, khususnya kuota atau paket data untuk pembelajaran. Kedua, kesempatan untuk mendukung dan mengontrol kegiatan putra-putrinya dalam mengikuti dan menyelesaikan tugas-tugas pembelajaran. Ketiga, pemahaman dan penerapan dalam pembelajaran daring, karena ada beberapa faktor. a. selama ini orang tua menyerahkan pendidikan dan pembelajaran sepenuhnya kepada pihak sekolah b. kurangnya pemahaman metode pembelajaran daring. Keempat, komunikasi orang tua dengan guru yang terkendala karena adanya pandemi.

\section{Pembahasan}

Pandemi covid-19 sampai saat ini masih menjadi permasalahan global, termasuk permasalahan bangsa Indonesia. Untuk mengatasi perlu kerjasama semua komponen masyarakat, termasuk di dalamnya proses pembelajaran harus mengedepankan pencegahan dan kesehatan warga masyarakat dalam hal ini guru, warga sekolah, termasuk dalamnya peserta didik. Maka pembelajaran jarak jauh (PJJ) atau daring merupakan opsi pembelajaran di masa darurat saat ini. Meski diakui dalam tataran pelaksanaan muncul berbagai problematika, di sini pembahasan difokuskan 3 bagian, yaitu bagian satu problematika yang dihadapi peserta didik, bagian dua problematika yang dihadapi guru dan bagian tiga problematika yang dihadapi orang tua. Selanjutnya pemecahan masalah yang ada.

Bagian satu, problematika yang dihadapi peserta didik, pertama, Paket data. pembelajaran daring merupakan pembelajaran yang menggunakan media pembelajaran dan jaringan internet, pembelajaran yang bergantung pada ketersediaan teknologi informasi (Haryadi \& Fitriani, 2021). Dalam pembelajaran daring peserta didik tidak hanya membutuhkan suasana di rumah nyaman dan tenang yang mendukung untuk belajar efektif, tetapi juga koneksi internet yang memadai dan tidak karena masih ada peserta didik yang tidak memiliki gawai ataupun paket (Rofi'ah, 2021; Sarwa, 2021). Selanjutnya Adriani (dalam Haryadi et al.,2021) mengingatkan akan tanggung jawab sekolah sebagai institusi, bahwa untuk mengatasi problematika pembelajaran daring di masa pandemi ini mengharuskan adanya ketersediaan infrastruktur dan platform yang mendukung proses kegiatan belajar mengajar.. Problematika tidak memiliki atau kurang paket data tentu sangat menghambat, karena sebagai prasyarat adanya jaringan internet dan penentu jalanya proses pembelajaran. maka harus segera diatasi. Mengingat masalah paket data merupakan problematika terbesar yang dialami peserta didik. Upaya pemberian stimulan paket data kepada semua peserta didik dan guru pada awal pandemi telah dilakukan. Diakui akibatkan Pandemi yang berkepanjangan maka problematika paket data masih menjadi dominan. Terlebih bagi keluarga korban PHK atau usaha terhenti akibat PPKM atau pembatasan aktivitas. Sebagai jalan keluar SMK Negeri 4 Yogyakarta 
memberikan solusi. Bagi peserta didik yang mengalami kesulitan akses internet dapat melakukan pembelajaran di Sekolah dengan penerapan protokol kesehatan secara ketat. Juga berupaya memberikan bantuan paket data dari dana sekolah, tidak kurang dari 80 juta sudah beriakan (wawancara Waka. Kurikulum, 19 Agustus 2021), bahkan hibah dari para guru yang peduli terhadap persoalan peserta didik.

Kedua, problematika jenuh, kurangnya semangat peserta didik dalam mengikuti pembelajaran. Sejak masa pandemi, awal Maret 2020 dan sampai saat ini belum menunjukkan akan berakhir, serta metode pembelajaran yang menekankan belajar dari rumah, tidak dapat dipungkiri membuat peserta didik kurang bersosialisasi dengan lingkungan dan temantemannya. Akibatnya peserta didik mengalami kejenuhan, semangat belajar menurun bahkan mudah depresi. Masalah ini menjadi serius, sebab dari hasil temuan rendahnya semangat nelajar di kalangan peserta didik merupakan problem terbesar bagi para guru di SMKN 4 Yogyakarta dalam pembelajaran daring. Guru sebagai penentu dalam proses pembelajaran harus memiliki strategi dan berbagai metode pembelajaran agar peserta didik tidak jenuh, bosan dan memiliki semangat mengikuti pembelajaran. jika perlu pembelajaran juga sebagai hiburan yang mendidik bagai peserta didik. sebagai solusi guru hendaknya menyiapkan materi pembelajaran semenarik mungkin, seperti penyajian materi dalam slide powerpoint disertai video pembelajaran agar materi lebih hidup dirasakan oleh peserta didik. Dan tugas guru adalah membangkitkan semangat belajar kepada peserta didik ketika kurang semangat (Asmuni, 2020; Basar, 2021). Dan model pembelajaran pada kurikulum 2013 diawali dengan upaya guru untuk menarik perhatian peserta didik dan memotivasi mereka agar terlibat dalam proses pembelajaran dari awal sampai akhir (Zahrawati, 2021).

Ketiga, konsentrasi belajar terganggu. Pembelajaran daring membutuhkan tanggung jawab secara mandiri dan kemandirian belajar. Namun dari data diakui bahwa belajar mandiri di rumah tidak mudah, banyak tantangan yang dihadapi oleh peserta didik dalam belajar. Banyak hal yang mempengaruhi; lingkungan keluarga yang kurang kondusif, konten-konten dalam Gawai atau laptop yang kurang mendukung pembelajaran, misalnya game atau konten lain yang lebih menarik perhatian anak. Terlebih jika kontrol orang tua dan lingkungan yang kurang. Akibatnya tugas-tugas pembelajaran sering terabaikan. Faktor-faktor penyebab gangguan konsentrasi belajar dapat dibagi menjadi dua yaitu ganguan eksternal (ganguan dari luar diri) dan internal (kondisi diri sendiri). (Mantu, 2015). Untuk mengatasi guru perlu menciptakan kondisi sebelum dan saat pembelajaran agar peserta didik dapat fokus mengikuti pembelajaran. Misalnya dengan membuat jadwal yang jelas dan dikomunikasikan dengan peserta didik, dan orang tua mendukung. Bagi peserta didik yang mengalami masalah konsentrasi ada problem solving dengan guru BK melalui whatsapp atau bisa datang ke sekolah. Disamping itu guru diharapkan membuat konten-konten pembelajaran dengan lebih kreatif dan menarik perhatian, dengan aplikasi dan metode pembelajaran dengan lebih variatif. Misalnya dengan kartun, video dengan power point dan lain sebagainya, dengan tujuan pembelajaran.

Keempat, kurangnya dorongan orang tua; faktor lingkungan dalam hal ini orang tua di rumah yang tidak mendukung menjadi permasalahan dalam pembelajaran daring (Mahpudin, 2021), kurangnya fasilitas belajar, dukungan dan dorongan kepada putra-putrinya menjadi hambatan. Maka peran orang tua sebagai pilar pendidikan sangat strategis dalam keberhasilan pendidikan, khususnya pada masa pandemi covid 19. Dari hasil wawancara ditemukan adanya hal sebaliknya, bukan mendorong untuk belajar tetapi justru anak diberdayakan membantu pekerjaan orang tua pada saat jam pembelajaran, karena terdesak ekonomi. Inilah tantangan pembelajaran daring. Upaya komunikasi guru dengan orang tua perlu dijalin dengan baik dengan memberi pemahaman akan tanggungjawab dan hak anak untuk belajar.

Kelima, Belum familiar dengan metode pembelajaran daring yang diterapkan. Diakui bahwa latar belakang dan asal sekolah peserta didik beragam. Ada sekolah asal peserta didik yang sudah melaksanakan pola pembelajaran daring, dan tidak menutup kemungkinan ada yang belum terapkan daring dengan berbagai alasan, dan masih menerapkan luring selama masa pandemi covid-19. Meski Prosentasenya sangat kecil tentu peserta didik ini tidak dapat 
mengikuti pembelajaran, bahkan akan kebingungan dan apatis. Untuk generasi melinial tentunya dengan pendampingan segera dapat beradaptasi. Mengacu hasil survei Melania terhadap siswa yang melakukan kegiatan pembelajaran daring. Hasilnya menunjukkan bahwa sebagian siswa menerima pembelajaran daring dengan alasan bahwa pembelajaran daring lebih santai, menyenangkan, fleksibel, efisien, singkat, praktis, cepat, tepat, aman, mudah, hemat waktu, dan hemat tenaga. (dalam Wahyono, Husamah \& Anton, 2020).

Keenam, pemakaian gawai bersama, memang perlu dipahami bahwa dengan peserta didik yang cukup besar, tidak menutup kemungkinan adanya keluarga kurang beruntung bahkan gawai harus bergantian orang tua atau saudara. Hal ini memang menghambat dalam pembelajaran daring. Bagi sebagian siswa yang tidak mempunyai gawai pribadi akan kesulitan dalam mengikuti pembelajaran terutama ujian. Maka diperlukan komunikasi antara peserta didik, guru dan orang tua. Sehingga ada solusi yang terbaik, misalnya fleksibilitas penyelesaian tugas peserta didik dapat mengerjakan tugas secara manual, terpenting tetap belajar dan berada di rumah. (Basar, 2021; Asmuni, 2020).

Ketujuh, jaringan stabil merupakan kunci lancarnya pembelajaran daring, tidak stabilnya jaringan menjadi hambatan yang perlu segera diatasi. Lokasi tempat tinggal peserta didik yang ada di pedalaman dan keterbatasan untuk jaringan internet memang menjadi persoalan (Mahpudin, 2021). Sepakat dendan kriteria media daring yang disukai peserta didik adalah menggunakan media yang irit kuota, tidak butuh jaringan kuat, dan mudah digunakan (Widodo, A \& Nursaptini, 2020). Solusi berikutnya thethering dengan anggota keluarga lainnya atau menghemat dengan cara connect saat dibutuhkan saja atau disarankan datang ke sekolah atau kelurahan terdekat, atau datang ke sekolah dengan protokol covid-19 secara ketat. Bagi peserta didik tidak yang masih kesulitan, disarankan mengikuti program pendidikan lewat siaran televisi yang diselenggarakan oleh Kementerian Pendidikan dan Kebudayaan bekerjasama dengan TVRI dalam rangka memfasilitasi pendidikan di masa pandemi Covid-19 di Indonesia, tentu saja dengan konten yang sesuai (Asmuni, 2020).

Bagian dua, problematika yang dihadapi guru. Pertama, kurangnya semangat belajar peserta didik. Kunci keberhasilan guru adalah jika guru dapat membangkitkan semangat belajar jika peserta didik mengalami patah semangat. Hendaknya mencari tahu akar permasalahan, dan solusinya tentu juga sesuai kasus yang dihadapi. Ada beberapa faktor kurangnya respon peserta didik dalam pembelajaran daring. Dari data, sebab kurangnya semangat peserta didik merasa jenuh, akibat akumulasi pembelajaran daring lebih 1,5 tahun dan metode pembelajaran yang kurang menarik. Maka guru hendaknya menyiapkan materi pembelajaran semenarik mungkin, seperti penyajian materi dalam slide powerpoint disertai video pembelajaran agar materi lebih hidup. (Asmuni, 2020). Sepakat yang disampaikan Asmui, untuk menghilangkan kejenuhan peserta didik ditawarkan guru hendaknya membuat materi pembelajaran yang lebih menarik dan dengan aplikasi yang lebih bervariatif. Bahkan pembelajaran sekaligus sebagai hiburan yang mendidik bagi peserta didik.

Kedua, kompetensi pembelajaran yang tidak tercapai, perlu diakui bahwa pembelajaran daring kurang efektif dibanding dengan pembelajaran tatap muka. Karena materi pembelajaran dari belum tentu bisa dipahami, kalaupun bisa dipahami, tidak komprehensif karena peserta didik memahami sesuai tafsiran masing-masing (Asmuni, 2020). Hal ini tentu akan mempengaruhi ketuntasan belajar, terlebih pelajaran produktif, yang membutuhkan keterampilan atau skill. Untuk itu di masa darurat ini perlu adanya regulasi penyederhanaan kompetensi juga standar kompetensi.

Ketiga, Penanaman karakter, Perlu dipahami bahwa tugas guru selaku pendidik tidak hanya mengajar tetapi juga menanamkan nilai-nilai karakter, sebagaimana UU Nomor 20 tahun 2003 Pasal 3 bahwa salah satu tujuan pendidikan adalah membentuk manusia yang berakal mulia (Lembaran Negara, 2013). Untuk mewujudkan tujuan tersebut pada masa pandemi ini tentu menjadi tantangan tersendiri bagi guru. Solusinya perlu ada komunikasi dan kolaborasi dengan orang tua untuk menanamkan karakter peserta didik. Keluarga, orang tua merupakan lokomotif utama dalam penanaman pendidikan karakter, yang perlu melakukan pengajaran, pembiasaan, 
peneladanan, pemotivasian, dan pendisiplinan aturan untuk mengembangkan karakter peserta didik. Sedangkan karakter yang ditanamkan di rumah yaitu (1) Nilai karakter religius, (2) Nilai karakter disiplin, (3) Nilai karakter kreatif, (4) Nilai karakter mandiri, (5) Nilai karakter tanggung jawab, dan (6) Nilai karakter rasa ingin tahu (Maria \& Rifma \&Syahril, 2021;Purandina \& Winaya, 2020). Jika peran orang berjalan dengan baik, maka saat pandemi ini guru tinggal mengontrol dan mengevaluasi.

Keempat, intensitas komunikasi, terbatasnya interaksi antara guru dan peserta didik pada masa pandemi ini, menjadi tantangan dan bisa menghambat proses pembelajaran. Dengan keterbatasan komunikasi langsung, solusi yang ditawarkan; guru hendaknya selalu berinteraksi dan berkomunikasi dengan baik dengan peserta didik, wali kelas maupun orang tua, terutama bagi peserta didik yang mengalami masalah dalam pembelajaran maupun materi pelajaran. Hal ini tidak sulit dilakukan mengingat alat komunikasi saat ini dimiliki hamper semua siswa dan orang tua. Memperkuat penelitian sebelunya bahwa dengan komunikasi, kolaborasi, kerja sama, dan koordinasi yang baik problematika pembelajaran akan teratasi (Wahyono et all, 2020)

Kalima, dalam pembelajaran daring penguasaan media pembelajaran berbasis teknologi dan informasi merupakan keharusan. Sehingga bagi guru tidak memahami akan mengalami kesulitan dalam pembelajaran. Maka guru dituntut senantiasa mengasah pengetahuan dan ketrampilan dalam metode pembelajaran daring. Bisa secara mandiri dengan tutorial, mengikuti pelatihan-pelatihan yang sekolah bahkan tim TIK sekolah siap mendampingi. Yaitu memahami aplikasi yang digunakan dalam pembelajaran daring, yaitu WhatsApp Group, Zoom Cloud Meeting, Google Classroom, Google Form, dan e-mail. Mengutip dari penelitian Wahyono dkk dalam Artikel guru profesional di masa pandemi covid-19, dalam konteks pembelajaran daring, apresiasi layak diberikan kepada guru yang cepat beradaptasi dengan perubahan dan cepatnya perkembangan teknologi informasi (Wahyono et all, 2020). Solusi ini yang dijadikan rujukan untuk mengatasi kurangnya pemahaman dan sulitnya penerapan pembelajaran daring.

Bagian tiga, Problematika yang muncul bagi orang tua. Pertama, masalah ekonomi, diakui dampak pandemi di sektor ekonomi cukup besar, baik dampak langsung ataupun tidak langsung, adanya covid-19 dengan PHK besar besaran dan PPKM, menjadi penyebab Usaha Mikro, Kecil, dan Menengah (UMKM) menjadi kelompok usaha yang memiliki jumlah paling besar dan paling merasakan dampaknya (Pratiwi, 2021). Akibatnya masyarakat menghadapi kesulitan, terlebih kelas menengah bawah. Sehingga untuk pemenuhan kebutuhan hidup seharihari sudah berat aplagi pemenuhan sarana belajar bagi putra-putrinya dengan biaya yang tidak kecil. Begitu juga masalah kesempatan orang tua dalam rangka mendampingi dan mengontrol putra-putri ini dalam menyelesaikan tugas belajar. Kesibukan bekerja mencari nafkah dalam memenuhi kebutuhan rumah tangga terkadang sampai melupakan tanggungjawab selaku orang tua. Adanya pemahaman yang keliru terhadap konsep pembelajaran bahwa pendidikan merupakan tugas anak dan guru di sekolah, menjadi problematika tersendiri. Selain masalah komunikasi orang tua dengan guru yang terkendala karena adanya pandemi. Solusinya, perlu adanya komunikasi, kolaborasi, kerja sama, dan koordinasi yang baik (Wahyono et all, 2020). Pentingnya pemahaman yang benar bahwa tanggungjawab pendidikan dan pembelajaran merupakan tanggungjawab bersama, peserta didik sebagai pelaku memiliki tanggungjawab belajar, orang tua, masyarakat dan guru/ sekolah sebagai pilar pendidikan. Orang tua memiliki tanggungjawab pendampingan selama waktu pembelajaran daring, paling tidak melakukan kontrol. Bagi orang tua mungkin berat untuk menerima karena biasanya tanggung jawab pendidikan anaknya diserahkan kepada guru atau pendidik, akibat pandemi ini terpaksa pembelajaran dilakukan di rumah dan mendampingi atau memantau anaknya agar pembelajaran daring dapat berjalan dengan efektif. Belajar secara daring memang memiliki tantangan tersendiri, peserta didik tidak hanya membutuhkan suasana nyaman dan tenang yang mendukung belajar efektif, tapi juga pendampingan orang tua selama proses belajar daring di rumah (Rofi'ah, 2021). Kesibukan orang tua dalam mencari nafkah, memang menjadi kekhawatiran dan ketakutan tersendiri, namun dengan kesadaran dan tanggungjawab orang tua 
tetap bisa mendampingi, memantau putra-putrinya dalam kegiatan belajar, ini menjadi sebuah ketakutan dan kekhawatiran tersendiri. Disisi lain peserta didik harus ditanamkan nilai-nilai kemandirian dan dikepercayaan untuk belajar menyelesaikan persoalan dan tugas secara mandiri karena SMK sudah dewasa sudah waktunya untuk bertanggung jawab dengan dirinya.

\section{KESIMPULAN}

Masa Pandemi covid-19 yang sampai saat masih menjadi masalah global, semua sektor harus mencari solusi dalam kondisi darurat agar roda kehidupan dan kegiatan tetap berjalan. Termasuk dunia pendidikan, pembelajaran diharapkan tetap berjalan meski dengan keterbatasan dan kekurangan. Yang terpenting adalah bagaimana mengurangi penyebaran covid-19 dan melindungi kesehatan masyarakat. Maka pembelajaran daring menjadi salah satu opsi yang realistis di SMKN 4 Yogyakarta. Mesti diakuni banyak kekurangan dan problematika yang ada. Problematika yang muncul dari peserta didik yang paling menonjol adalah masalah paket, kurangnya semangat karena sudah jenuh, kurang konsentrasi dalam belajar, kurangnya dorongan dari orang tua, kurangnya pemahaman dalam pembelajaran daring, masalah pemakaian gawai secara bersama dan masalah jaringan bagi sebagian kecil peserta didik. Kemudian problematika yang dihadapi guru yang menonjol adalah kurangnya semangat belajar peserta didik, kurangnya kompetensi, penanaman karakter, intensitas kompetensi dalam pembelajaran dan masih adanya sebagian kecil guru yang kesulitan dalam pembelajran daring yang harus menggunakan TI. Sedangkan problematika yang muncul dari orang tua diantaranya adalah masalah ekonomi yang menurun, kesempatan mendampingi, kurangnya pengetahuan dalam memahami pembelajaran daring dan masalah komunikasi dengan guru atau sekolah.

Solusi pemecahan dari problematika pembelajaran daring di SMKN 4 Yogyakarta, secara garis besar perlu pemahaman yang sama akan tanggung jawab dalam pendidikan dan pembelajaran merupakan tanggung jawab bersama antara guru, peserta didik dan orang tua. Disamping itu perlu adanya komunikasi yang baik antara ketiga unsur tersebut. Dengan demikian problematika yang ada dapat dicari solusi yang terbaik. Masalah kurangnya ekonomi paket data, jaringan, bahkan masalah pengadaan gawai atau gawai bagi peserta didik yang tidak memiliki sendiri dipecahkan dengan kolaborasi orang tua dan guru. Masalah kurangnya pemahaman dan penerapan pembelajaran dipecahkan dengan mengadakan pelatihan metode pembelajaran dari bagi guru terutama dan pendampingan bagi peserta didik. Masalah kesempatan dan sarana pembelajaran, orang tua dan peserta didik diharapkan membuat skala prioritas. Masalah kurang semangat karena jenuh, kurang konsentrasi dalam belajar, solusinya guru diharapkan melaksanakan pembelajaran dengan kreatif, inovatif dan menarik. Bahkan pembelajaran bisa sekaligus hiburan dan peserta didik selalu merindukan. Sedangkan masalah capaian kopetensi karakter dalam situasi darurat perlu ada rekonstruksi kompetensi substansial dan yang tidak, dan dalam penanaman karakter perlu strategi dan penilaian yang sesuai.

Penelitian ini diharapkan sebagai referensi, informasi dan acuan dalam penelitianpenelitian berikutnya, serta menjadi bahan pertimbangan dalam pengambilan kebijakan bagi instansi terkait, terutama SMKN 4 Yogyakarta. Semoga bermanfaat.

\section{DAFTAR PUSTAKA}

Anggito, Albi \& Setiawan, Johan. (2018). Metode Penelitian Kualitatif : Metodologi penelitian kualitatif. Jawa Barat: CV. Jejak Sukabumi.

Asmuni. (2020). Problematika Pembelajaran Daring di Masa Pandemi Covid-19 dan Solusi Pemecahannya. Jurnal Paedagogi: Jurnal Penelitian dan Pengembangan Pendidikan, . Volume 7 Nomor 4, halaman 281-288.

Basar, Afip Miftahul. (2021). Problematika Pembelajaran Jarak Jauh Pada Masa Pandemi Covid-19 (Studi Kasus di SMPIT Nurul Fajri - Cikarang Barat - Bekasi), E: Jurnal Ilmiah Pendidikan, dunesia, Vol. 2, No 1 Hal. 208 - 218 
Haryadi, Rudi \& Selviani, Fitria. (2021). Problematika Pembelajaran Daring Di Masa Pandemi Covid-19. Academy of Education Journal, Volume 12 Nomor 2, Juli 2021, Hal 254261.

Keputusan Bersama Menteri Pendidikan dan Kebudayaan, Menteri Agama, Menteri Kesehatan dan Menteri Dalam Negeri No. 01/KB/2021, No. 516 Tahun 2020, No.HK.03.01/Menkes/363/2020, dan No. 440-882 tentang Panduan PenyelenggaraanPembelajaran pada Tahun Ajaran 2020/2021 dan Tahun Akademik 2020/2021 dimasa Covid-19 Menteri Pendidikan. (2020).

Mahpudin, Pupu. (2021). Implementasi Pembelajaran Pendidikan Agama Islam Berbasis Google Classroom. Jurnal Aksioma Ad-Diniyyah : The Indonesian Journal of Islamic Studies, Vol. 9, No.1, Hal 45-56

Mantu, Joko, (2015), Peran Guru Dalam Meningkatkan Konsentrasi Belajar Siswa Pada Mata Pelajaran Pendidikan Agama Islam (Pai) Di Sma Negeri 9 Manado. Skriptsi, Institut Agama Islam Negeri (IAIN) Manado.

Maria, Rika \& Rifma \& Syahril (2021), Efektivitas Pembelajaran Dan Pembinaan Karakter Di Masa Pandemi Covid-19, Jurnal Pendidikan, Edukasi, Universitas Pahlawan Tuanku Tambusai, Vol 3, No 4. https://www.edukatif.org/index.php/edukatif/article/view/566/pdf

Nugraheni, Farida. (2014). Metode Penelitian Kualitatif dalam penelitian Pendidikan Bahasa, Uiversitas Bantara.ac.id. http://digilibfkip.univetbantara.ac.id/materi/Buku.pdf

Pratiwi , Maya Intan. (2020). Dampak Covid-19 Terhadap Perlambatan Ekonomi Sektor UMKM, Jurnal Nurs, Lembaga Penelitian, Universitas Pahlawan Tuanku Tambusi, Vol 4, No 2.

Purandina, I Putu Yoga \& Winaya, I Made Astra (2020), Pendidikan Karakter di Lingkungan Keluarga Selama Pembelajaran Jarak Jauh pada Masa Pandemi COVID-19. Jurnal Cetta: Jurnal Ilmu Pendidikan, Sekolah Tinggi Agama Hindu Negeri Mpu Kuturan Singaraja Jayapangus Press, Vol. 3 No. 2. Hal. 270-290.

Raco, J.R. Dr., ME, M.Sc. (2010). Metode Penelitian Kualitatif, Jenis, Karakteristik dan Keunggulan. PT. Gramedia Widiasarana Indonesia. Jakarta. https://osf.io/mfzuj

Rofi'ah, Risatur. (2021). Problematika Orang Tua Mendampingi Anak Saat Pembelajaran Daring Di Masa Pandemi Covid 19 dan Solusi Pemecahannya. Jurnal Bimbingan dan Konseling Islam Institut Pesantren Sunan Drajat, Vol. 01 No. 01 (April 2021), Hal. 5258

Sarwa, S.S.,M.M. (2021). Pembelajaran jarak: konsep dan solusi. Indramayu Jawa Barat : CV. Adanu abimata.

Surat Edaran Menteri Pendidikan dan Kebudayaan Nomor 36952/MPK.a/HK/2020, tanggal 17 Maret Tahun 2020, Tentang Pembelajaran secara Daring dan Bekerja dari Rumah untuk mencegah penyebaran CoronaVirus (COVID-19).

Undang-undang Nomor 20 tahun 2003 tentang Sistem Pendidikan Nasional, (Lembaran Negara Republik - 3 - Indonesia Tahun 2003 Nomor 78, Tambahan Lembaran Negara Republik Indonesia Nomor 4301);.

Wahyono, Poncojari \& Husamah, H \& Budi, Anton Setia. (2020). Guru profesional di masa pandemi COVID-19: Review implementasi, tantangan, dan solusi pembelajaran daring. Jurnal Profesi Guru Universitas Muhammadiyah Malang, Volume 1 No 1 Tahun 2020, Hal 51-65

Wahyuningsih, Kompyang Sri. (2021). Problematika Pembelajaran Daring Di Masa Pandemi Covid-19 Di Sma Dharma Praja Denpasar. Jurnal Pangkaja Pasca Sarjana Universitas Hindu Negeri Denpasar Bali, VOL. 24 NO. 1, MARET 2021. Hal $108-118$

Widodo, A. Nursaptini. (2020). Problematika Pembelajaran Daring dalam Perspektif Mahasiswa. Elementary School Education Journal (ELSE). Volume 4 Nomor 2, halaman 100-115. http://journal.um-surabaya.ac.id/index.php/pgsd/article/view/5340 
Zahrawati, Fawziah. (2021). Penerapan Pembelajaran Daring dengan Kurikulum 2013 pada Masa Pandemik COVID-19 di SMA Negeri 1 Nunukan, Jurnal Ilmiah Iqra', Institut Agama Islam Negeri (IAIN) Manado, Vol. 15 No. 1 Hal 48-58. 